\title{
Ethnobotany of Amorphophallus paeoniifolius: Morphology, folk classification, and habitat in area around Mt. Ciremai, Cimanuk Watershed Region, West Java, Indonesia
}

\author{
ASEP ZAINAL MUTAQIN ${ }^{1,2}$, DENNY KURNIADIE ${ }^{1}$, JOHAN ISKANDAR ${ }^{1,2}$, MOHAMAD NURZAMAN $^{1}$, \\ RUHYAT PARTASASMITA ${ }^{1, v}$ \\ ${ }^{1}$ Department of Biology, Faculty of Mathematics and Natural Sciences, Universitas Padjadjaran. Jl. Raya Bandung-Sumedang Km 21 Jatinangor, \\ Sumedang 45363, West Java, Indonesia. Tel.: +62-22-7796412 line. 104, Fax.: +62-22-7794545, `email: ruhyat.partasasmita@unpad.ac.id \\ ${ }^{2}$ Program of Environmental Science, Postgraduate School, Universitas Padjadjaran. Jl. Dipati Ukur 35, Bandung 40132, West Java, Indonesia
}

Manuscript received: 6 July 2020. Revision accepted: 31 July 2020.

\begin{abstract}
Mutaqin AZ, Kurniadie D, Iskandar J, Nurzaman M, Partasasmita R. 2020. Ethnobotany of Amorphophallus paeoniifolius: Morphology, folk classification, and habitat in area around Mt. Ciremai, Cimanuk Watershed Region, West Java, Indonesia. Biodiversitas 21: 3898-3909. Plants that grow in the world have a diversity of names, characters, and growing environments. Likewise, plants that grow around Mt. Ciremai, including the Cimanuk Watershed, are very diverse in species and habitats. One species of plant in this region is Amorphophallus paeoniifolius (Dennst.) Nicolson. This plant is closely related to people's lives. This plant is a species of the tuber that has the potential to be used for various purposes. This study aims to determine the knowledge of the people about the ethnobotany of A. paeoniifolius especially the morphology, folk classification, and habitat with case studies in several villages in Cikijing Sub-district, Majalengka District which is ecologically located in the Mt. Ciremai neighborhood and, based on geography, is included in the Cimanuk Watershed. The qualitative method is used in this research. The data were collected through observation and semi-structured interviews or deep interviews with competent communities by focusing on their diversity. Data were analyzed by cross-checking, summarizing, and synthesizing and were narrated descriptively through an emic and ethical approach. The results showed that the people in the Mt. Ciremai neighborhood, namely Cipulus Village, Cilancang Village, Jagasari Village, and Sindangpanji Village, Cikijing Sub-district, Majalengka District knew names, morphology, and folk classification of A. paeoniifolius. This plant is popularly known as suweg in local name. People's knowledge related to morphology (leaves, tubers, roots, and flowers) in these areas is generally not much different. Related to folk classification, people generally say that suweg has variant based on the color of the tubers and sunlight exposure to the place of growth. The intended variant is suweg with reddish-white and yellowish-white of the tuber flesh's color. Another classification is the suweg variant which grows in the hieum (shading area) and negrak (open area). Concerning hábitat, the people informed that the suweg grows in the garden and homegarden (specifically in the Sindangpanji village, the people said that besides growing in both types of land, the suweg also grows on the edge of rice fields and ponds). Besides, suweg also grows in hot and cold (tiis) conditions; from the beginning of the rainy season to the beginning of the dry season, which is marked by yellowing and falling of leaves; in various soil conditions (such as red, black, brown or sandy soil); and with various species of plants (except with eurih and areuy, in which the growth of the plant is not optimum).
\end{abstract}

Keywords: Cimanuk Watershed, Mount Ciremai, ethnobotany, suweg

\section{INTRODUCTION}

Indonesia is one of the richest centers of biodiversity in the world in terms of numbers and endemics, both at the genetic, species and ecosystem levels. One of the intended biodiversity is plants. Globally, plants are very diverse. There are many numbers of plant species that grow in the world. The species of plants spread in various regions with vastly varying areas. Plants also live in certain environmental conditions. The environment in question consists of the natural and built environment. The natural environment is an environment that is rarely or never managed by humans, like natural forests. An artificial environment is an environment that is managed by humans such as home gardens, gardens, and rice fields. The distribution and growth of plants are influenced by environmental factors such as edaphic, climate, and biology. For example, Dou et al. (2017) mention that light affects plant growth, specifically the herb group. Meanwhile, Derebe et al. (2019) inform that growth and physiology such as leaf number, shoot number, leaf area, and leaf area. Stomata number, stomata opening area, stomatal conductance are affected by exposure to ultraviolet Blight at different altitudes.

In addition to biophysical factors, the distribution and growth of plants are also influenced by socio-cultural factors. Hassan and Hassan (2019) states that human activities affect the distribution, composition, and diversity of plant species. Xu et al. (2019) inform that human activities have shaped large-scale distributions of many plant species, driving both range contracts and expansions. Plants and humans have a very close relationship. Plants, especially those that grow in the built environment, are important resources for human life to fulfill their lives. Humans use plants as food, clothing, building materials, and fuel. The relationship between humans and plants is not only related to biological aspects, but also involves other aspects such as social, cultural, and spiritual (Caruso and Grace 2015).

Amorphophallus paeoniifolius (Dennst.) Nicolson is one species of plant that is widely distributed in various regions of the world. This plant spreads in various types of 
land and topography such as in some areas of the watershed with a diversity of ecosystems. Specifically, the watershed is the geographical area drained by a watercourse (FAO 2017). Another definition, a watershed is a land area as an integral part of a river and its tributaries, which functions to accommodate, store and flow water coming from rainfall to lakes or the sea naturally, the boundary on land is the topographic separator and the boundary at sea until is water areas that are still affected by land activities (Government Regulation of the Republic of Indonesia Number 37 of 2012). More clearly, Mandal et al. (2016) inform the distribution of this plant covers several regions in several Asian countries such as India and Indonesia which are widely cultivated by residents. Ravi et al. (2011) state that A. paeoniifolius is widely cultivated in the Philippines, Indonesia, Malaysia, Bangladesh, India, and China. Specifically, in Indonesia, this plant is very widespread in various regions (Yuzammi et al. 2017).

Every human group, especially ethnic groups or local peoples, knows many ways. This knowledge is known as traditional knowledge or indigenous knowledge or local knowledge. Traditional knowledge is part of local wisdom which is the substance of knowledge from the results of intellectual activities in the traditional context, skills, innovation, and practices of indigenous and local communities that cover traditional ways of life, both written and unwritten delivered from one generation to the next related with protection and management of the environment and natural resources in a sustainable manner (Regulation of the Ministry of Environment and Forestry of the Republic of Indonesia Number P. 34 of 2017). Knowledge is gained through extensive experience in a specific place, landscape, or ecosystem and carried from one generation to the next (Curci 2010). Local knowledge, an essential part of traditional culture, is rooted in the ideal society, practice, relations, custom, and culture of the native community (Guo 2010; Wang 2017). Local knowledge is thick with local language or terms (Watson 2011; Iskandar 2018). Local knowledge of the people, more specifically traditional ecological knowledge, can support their way of life to adapt to new environmental and socio-economic changes (Phungpracha et al. 2016). Traditional and local knowledge is not static, but rather dynamic in its characteristics, ingrained in the culture and social changes (Kohsaka and Rogel 2019).

Regarding plants, local people have unique knowledge in terms of characteristics, classification, habitat, use, or others. Mao et al. (2018) state that plant utilization is an essential component of traditional knowledge. Zambrana et al. (2014) revealed that in general the knowledge of the people was related to gender, age, and ethnicity. This local knowledge is more specifically popular with the ethnobotany term, namely knowledge or the study of the dynamic relationships between plants and people (Voeks 2017). Ethnobotany generally examines the cultural perceptions of local peoples (emic views) and is interpreted with modern science (ethical views) (Martin 1995; Iskandar 2018).

Amorphophallus paeoniifolius is a species of plant that has a relationship with human life. This plant is often used by peoples for various purposes. Mutaqin et al. (2018; 2020a) inform that this plant is used by the community for food, fish food, and traditional ceremonial purposes. Besides, Yuzammi (2018) informed that this species of Amorphophallus can be used as food.

Specifically, in the Cimanuk watershed, $A$. paeoniifolius generally grows in the built environment or ecosystem. The Cimanuk watershed stretches in the West Java Province, empties into the Java Sea. This watershed covers several districts, namely Garut, Bandung, Sumedang, Majalengka, and Indramayu. The Cimanuk watershed has several vital objects of the state such as the Jatigede Reservoir and West Java International Airport. The Cimanuk watershed area has diverse ecosystems, ranging from mountainous ecosystems to coastal marine ecosystems with diverse types of land and topography. One of the mountainous ecosystems in this watershed is the western and southern regions of Ciremai Mount, more specifically in areas that are administratively included in Cikijing Sub-district, Majalengka District. Mt. Ciremai itself is a national park. Based on observations, in some rural areas, A. paeoniifolius is found to grow at various altitudes and land types. Also, residents in this region still use this species of Amorphophallus. Studies on $A$. paeoniifolius is still rarely conducted in this region. Thus, it is important to conduct a study of ethnobotany, especially related to the community's knowledge about this Amorphophallus species, more specifically about morphology, folk classification, and hábitat aspect.

\section{MATERIALS AND METHODS}

\section{Study area}

This research was conducted in January-July 2020 in several villages administratively included in Cikijing Subdistrict, Majalengka District, West Java Province, Indonesia (Figure 1). The data was randomly selected based on consideration of found objects, populations of objects, and altitude. The villages in question are Cipulus, Cilancang, Jagasari, and Sindangpanji. This study area is ecoregional and included in the Cimanuk watershed and around the Mt. Ciremai National Park. The study area is divided into three categories, namely Cipulus Village and Cilancang Village, which are categorized as close to Mt. Ciremai National Park, Jagasari Village are categorized rather far from Gunung Ciremai National Park, and Sindangpanji Village is categorized far from Mt. Ciremai National Park. Geographically, Cipulus Village has an altitude of 890 meters above sea level with an area of 3.45 ha, and the distance to the capital of sub-district and district is 7 and $40 \mathrm{~km}$, respectively. Cilancang Village is located at an altitude of 870 meters above sea level with an area of 1.99 ha, and the distance to the capital of sub-district and district is 7.20 and $40 \mathrm{~km}$, respectively. Jagasari Village has an altitude of 652 meters above sea level with an area of $5.70 \mathrm{ha}$, and the distance to the capital of sub-district and district, respectively, is 3 and $39 \mathrm{~km}$. Meanwhile, Sindangpanji Village is at an altitude of 629 meters above sea level with an area of 3.50 ha, and the distance to the 
capital of sub-district and district, respectively, is 2.5 and $35.5 \mathrm{~km}$ (Statistics of Majalengka District 2018). Demographically, the number of populations in rural areas around Mt. Ciremai National Park is less than in urban areas. More specifically, Cipulus Village has a population of 2,136 people with a density of 619 people $/ \mathrm{km}^{2}$, Cilancang Village has a population of 1,254 people with a density of 630 people $/ \mathrm{km}^{2}$. Jagasari Village has a population of 4,347 people with a density of 763 people $/ \mathrm{km}^{2}$, and Sindangpanji Village has a population of 4,287 people with a density of 1,225 people $/ \mathrm{km}^{2}$ (Statistics of Majalengka District, 2019). Meanwhile, the profession of the population around Mt. Ciremai National Park is generally farmers. Specifically, Cipulus Village consists of 559 farmers, 510 farm workers, 40 private workers, 7 civil servants, 10 craftsmen, 63 traders, 58 breeders, and 3 mechanics/public transport sectors. The occupation of the population in Cilancang Village is 425 farmers, 100 farm laborers, 14 civil servants, 10 traders, and 7 breeders. The occupation of the population in Jagasari Village is 891 farmers, 285 farm laborers, 24 private laborers, 22 civil servants, 4 craftsmen, 76 traders, 18 breeders, and 4 mechanics/public transportation sector. The occupation of the population in Sindangpanji Village is 600 farmers, 120 farm laborers, 1,122 private laborers, 45 civil servants, 450 traders, 25 breeders, and 102 mechanics/public transportation sector (Statistic of Majalengka District 2018).

Potential or agricultural commodities, plantations, fisheries, and livestock in Cikijing Sub-district, in general, are rice, corn, soybeans, peanuts, cassava, sweet potatoes, scallions, onions, large chilies, cayenne pepper, mushrooms, red beans, long beans, water spinach, cauliflower, potatoes, cucumber, cabbage, Chinese cabbage, tomato, carrot, banana, rambutan, avocado, star fruit, durian, guava, water guava, mango, mangosteen, jackfruit, papaya, salak, soursop, bread, carp, catfish, goldfish, tilapia, sepat, tawes, cows, goats, sheep, and chickens (Statistics of Majalengka District 2019). Specifically, agricultural and livestock commodities in Cipulus Village are coffee, cloves, ginger, cattle, sheep, free-range chickens, and broilers. Cilancang village has potential or agricultural commodities including rice, cloves, ginger, buffalo, sheep, free-range chickens, broilers, and laying hens. Jagasari village has the potential or agricultural commodities of rice, coffee, cloves, ginger, fish, buffalo, sheep, free-range chickens, and broilers. Meanwhile, Sindangpanji Village has potential or agricultural commodities including rice, coffee, cloves, ginger, fish, cattle, buffalo, sheep, free-range chickens, broilers (Cikijing District Agricultural Counseling Center 2019).
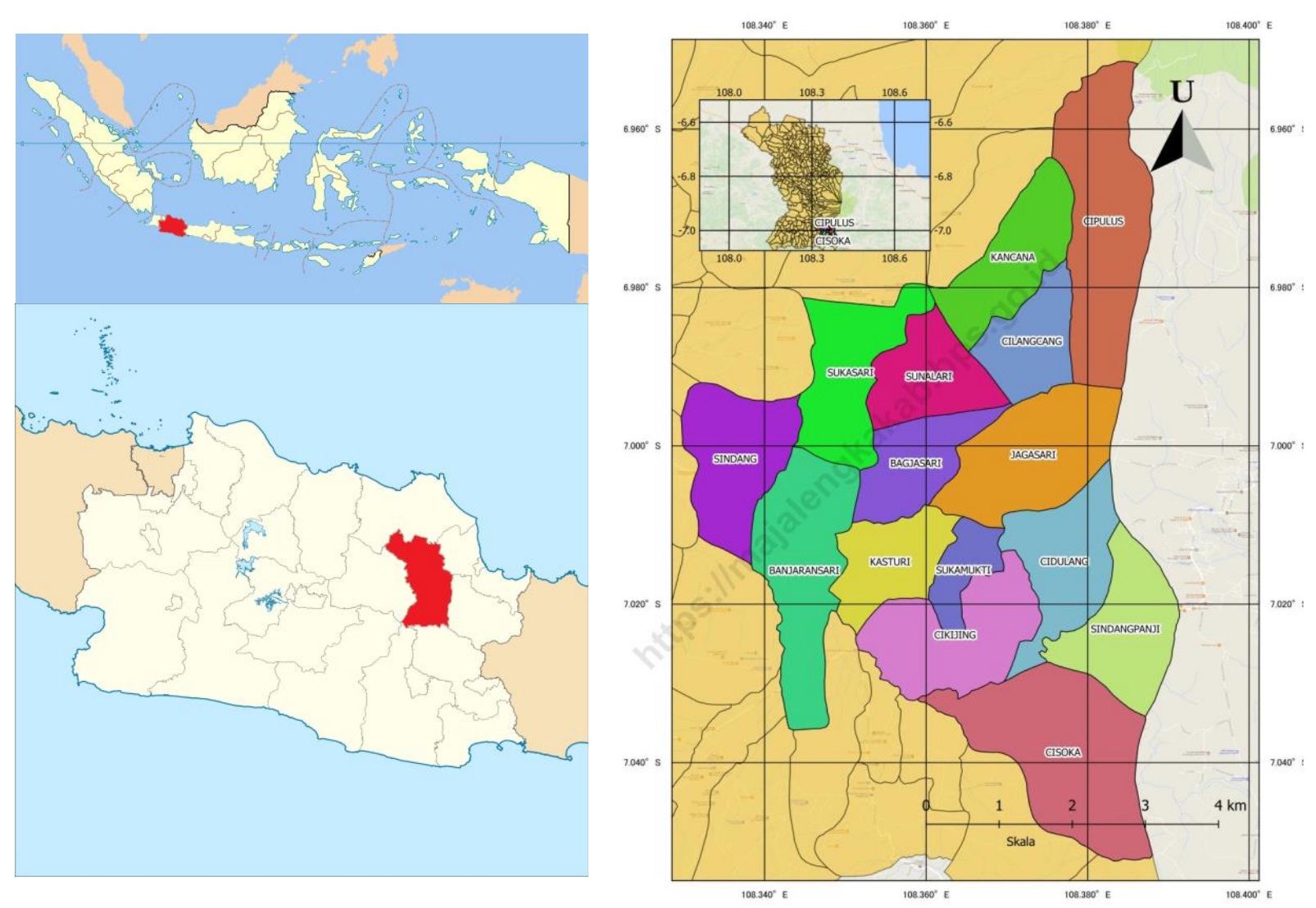

Figure 1. Location of research in the Sub-district of Cikijing, the District of Majalengka, West Java, Indonesia (Statistic of Majalengka District 2018) 


\section{Procedures}

This research is a qualitative ethnobotany study (Iskandar 2018). Data collection is more emphasized on triangulation techniques to make more comprehensive understanding (Albuquerque et al. 2014). The research data was collected by conducting surveys, observations, and interviews with residents. A survey was conducted to find out the existence of the suweg in the Cikijing Sub-district, Majalengka District. Observations and interviews were carried out to carry out intensive research in several locations that have been determined. The observation was carried out by observing and recording various land uses by landowners such as home gardens and gardens to validate that in the study area there were growing suweg. Observations were also made to note several other aspects that were considered important. Interviews with residents were carried out to find out residents' knowledge about the suweg, specifically about the morphology, habitat, and conservation of the suweg. The conducted interview is a semi-structured or in-depth interview. Interviews were conducted with the snowball technique to informants who were assumed to have competent knowledge about suweg by paying attention to diversity through purposive selection (Martin, 1995; Iskandar 2018). The informants in this study are the head and apparatus of the village administration, some farmers, community leaders, and landowners where the suweg grows or is found.

\section{Data analysis}

Data analysis emphasizes the concept of triangulation to test the credibility of the data. Data were analyzed by cross-checking, summarizing, and synthesizing for later narrative descriptive analysis through an emic and ethical approach (Newing et al. 2011; Iskandar 2018). Crosschecking is done to validate data or information from various informants, based on observations and reports. Valid data resulted from cross-checking are then summarized and synthesized and then described sequentially. Meanwhile, the emic and ethical approach in question is comparing the knowledge of the population in certain aspects with the results of studies or scientific research.

\section{RESULTS AND DISCUSSION}

Communities in Cikijing Sub-district, namely Cipulus Village, Cilancang Village, Jagasari Village, and Sindangpanji Village, have knowledge of the morphology, classification, and habitat of the suweg which is more clearly elaborated in the subtitles below:

\section{Morphology and folk classification of the suweg}

The communities informed that Amorphophallus which grows in the surrounding environment is popular with the local name of suweg. This plant has the scientific name of A. paeoniifolius. Furthermore, the community informed that the suweg has several characteristics based on morphology which can be fully seen in Table 1 and Figure 1.
In general, Table 1 informs that there are similarities and differences in community knowledge in each region. For example, when mentioning the morphology of tuber based on sap and taste some mention only a few aspects with language and meaning that are more or less the same meaning, but some mention it in more detail with the specific language, meaning, and terminology.

Specifically, Table 1 informs that there are several local languages or terms used in mentioning morphological features such as panci, peureup, ember, ceret, ceceting, boboko, baskom, dempak, herang, leueur, cakial, cawor, pulen, hipu, and cambewek. Panci is a cylindrical object made of aluminum and serves to contain or store curry, rice, water, and so on. The meaning of peureup is a fist. Ember is a container for water. Cerek is a container of drinking water that is usually brought to the field rice. Ceceting is a tool made from bamboo that functions to take water, oil, or something else from a large container. Boboko is a container of rice made from woven bamboo. Baskom is a tool made of zinc or aluminum which is used as a container for rice, water, and something else. Dempak means oval round. Herang means clear. Leueur shows the slippery liquid condition. Cakial means chewy. Cawor means delicious or good taste. Pulen means delicious or good taste. Cangor means not soft. Hipu means soft. Cambewek means cold or no taste.

In addition, Table 1 also informs that there is a diversity of community's perceptions regarding the size of the weight of tuber which is analogous to the size of certain tools or items that are around the environment and are popular in their use. For example, the tuber weight of $2 \mathrm{~kg}$ according to the people of Cipulus Village is the size of a coconut, while according to the people of Cilancang Village the size of a panci.

Table 1 informs that community's knowledge in some villages about the morphology of the root of suweg is generally the same, although there is information in more detail. The similarity in question such as the public's knowledge or perception is related to morphology-based on shape. Examples of more detailed knowledge in question are like knowledge related to morphology-based on size.

In addition, there is also local terminology or language used by the community in explaining the morphology of the root of suweg based on their perception or knowledge. The local terminology in question is buleud and sa jeungkal. Buleud has the meaning of a round shape. Sa jeungkal is a unit of length that is indicated by the length from the tip of the thumb to the tip of the pinkie when the palms are stretched.

Table 1 informs that in general, the community's knowledge of suweg leaves is the same, although there are differences in perceptions in certain aspects and informs in more detail. The difference in question is for example related to the color and height of the stems perception. Meanwhile, more detailed information in question is like knowing about the petiole. Communities in the Cilancang Village inform that the size of the stem is an indicator of tuber size. 
Table 1. Knowledge of the communities around Mt. Ciremai, West Java, Indonesia about the morphology of suweg

\begin{tabular}{|c|c|c|c|c|}
\hline \multirow{2}{*}{ Description } & \multicolumn{4}{|c|}{ Village } \\
\hline & Cipulus & Cilancang & Jagasari & Sindangpanji \\
\hline \multicolumn{5}{|l|}{ Tubers } \\
\hline Weight & $\begin{array}{l}\text { About } 3 \mathrm{~kg} \text { (the size of a } \\
\text { small panci) or } 2 \mathrm{~kg} \text { (the size } \\
\text { of a coconut) /the size of a } \\
\text { peureup }\end{array}$ & $\begin{array}{l}\text { About } 2 \mathrm{~kg} / 3 \mathrm{~kg} \text { (the size } \\
\text { of panci) } / 5 \mathrm{~kg} \text { (the size of } \\
\text { ember) } / 8 \mathrm{~kg} \text { (the size of a } \\
\text { ceceting } / \mathrm{soccer} \text { ball; } \\
\text { diameter } 25 \mathrm{~cm}\end{array}$ & $\begin{array}{l}\text { Around } 4 \mathrm{~kg} \text { (as big as } \\
\text { cerek/coconut/human } \\
\text { head/ceceting /small ember) } / 5 \\
\mathrm{~kg} \text { (as big as boboko) } / 10 \mathrm{~kg} \text { (as } \\
\text { big as baskom) }\end{array}$ & $\begin{array}{l}\text { Around } 5 \mathrm{~kg} \text { (as } \\
\text { big as an ember) }\end{array}$ \\
\hline Shape & Round & $\begin{array}{l}\text { Round/dempak; concave } \\
\text { in the middle }\end{array}$ & Dempakd/round like a ball & Round \\
\hline Color & $\begin{array}{l}\text { Tuber flesh is reddish-white; } \\
\text { tuber skin is blackish- } \\
\text { brown/black }\end{array}$ & $\begin{array}{l}\text { Tuber flesh is yellowish- } \\
\text { white/reddish-white; tuber } \\
\text { skin is brown/blackish } \\
\text { brown }\end{array}$ & $\begin{array}{l}\text { Tuber flesh is reddish- } \\
\text { white/yellowish-white; tuber } \\
\text { skin is brown/blackish brown }\end{array}$ & $\begin{array}{l}\text { Tuber flesh is } \\
\text { reddish-white }\end{array}$ \\
\hline Sap & Clear/yellowish; itchy & Clear as water; itchy & $\begin{array}{l}\text { Clear (herang)/yellowish; } \\
\text { slippery (leueur) }\end{array}$ & Clear \\
\hline Taste & $\begin{array}{l}\text { Cakial; rather sweet; odorless; } \\
\text { pulen/cawor }\end{array}$ & $\begin{array}{l}\text { Cakial; springy; sweet } \\
\text { taste; pulen }\end{array}$ & $\begin{array}{l}\text { Cakial; springy; sweet taste like } \\
\text { yam; old tubers are pulen, } \\
\text { young are cangor and itchy; } \\
\text { hipu }\end{array}$ & $\begin{array}{l}\text { Cakial like taro; } \\
\text { cambewek; } \\
\text { pulen }\end{array}$ \\
\hline \multicolumn{5}{|l|}{ Root } \\
\hline Shape & Round (buleud) & Round (buleud) & Round (buleud) & Round (buleud) \\
\hline Size & $\begin{array}{l}\text { Length of about } 5 \mathrm{~cm} / 20 \mathrm{~cm} \\
\text { (sa jeungkal) /the size of the } \\
\text { index finger }\end{array}$ & $\begin{array}{l}\text { Length of about } 5 \mathrm{~cm} \text { (the } \\
\text { size of the index finger) } \\
/ 10 \mathrm{~cm} / 20 \mathrm{~cm} / 25 \mathrm{~cm} / \mathrm{sa} \\
\text { jeungkal }\end{array}$ & $\begin{array}{l}\text { Length of about } 10-15 \mathrm{~cm} / \mathrm{sa} \\
\text { jeungkal }\end{array}$ & $\begin{array}{l}\text { About } 10 \mathrm{~cm} \text { in } \\
\text { length }\end{array}$ \\
\hline Others & Few & $\begin{array}{l}\text { The roots are in the upper } \\
\text { tubers; a little; a lot of } \\
\text { roots when young, few /no } \\
\text { root when old. }\end{array}$ & $\begin{array}{l}\text { Root near the petiole; fibrous } \\
\text { root-like taro roots }\end{array}$ & Grow on tuber \\
\hline \multicolumn{5}{|l|}{ Leaves } \\
\hline Leaf-blade & $\begin{array}{l}\text { Color is light or dark } \\
\text { green/dark; shape like an } \\
\text { umbrella } \\
\text { (rampidak/rubak/ngadimprak) }\end{array}$ & $\begin{array}{l}\text { Color is light green; shape } \\
\text { is ngadimprak; serrated } \\
\text { leaf edge (reregean) }\end{array}$ & Shape is rampidak & $\begin{array}{l}\text { Shape is } \\
\text { rampidak }\end{array}$ \\
\hline Petiole & $\begin{array}{l}\text { Green-white bottled/spotted; } \\
\text { slippery surface } \\
\text { (lesang/limit/teu kasap); } \\
\text { gummy; itchy, ends branching } \\
3 \text {; about } 1 \mathrm{~m} \text { in height }\end{array}$ & $\begin{array}{l}\text { Green/light green/dark } \\
\text { green/yellowish-white } \\
\text { green bottled/spotted; } \\
\text { smooth } \\
\text { surface/lesang/limitlteu } \\
\text { kasap; sap is clear; itchy; } \\
\text { ends branching } 3 \text {; about } 80 \\
\mathrm{~cm} / 1 \mathrm{~m} / 1.5 \mathrm{~m} / 2 \mathrm{~m} \text { in } \\
\text { height; round shape, } \\
\text { nyeprot }\end{array}$ & $\begin{array}{l}\text { Green-white bottled/spotted; } \\
\text { surface is lesang; sap is clear } \\
\text { (yellowish), slippery (leueur); } \\
\text { ends branching } 3 \text {; round shape; } \\
\text { about } 1 \mathrm{~m} / 1.25 \mathrm{~m} \text { (chest } \\
\text { height); } 1.5 \mathrm{~m} \text { (sa tangtung) in } \\
\text { height }\end{array}$ & $\begin{array}{l}\text { Green-white } \\
\text { stripes; surface } \\
\text { is lesang; sap } \\
\text { like taro sap; } \\
\text { itchy; about } 1 \mathrm{~m} \\
\text { in height }\end{array}$ \\
\hline \multicolumn{5}{|l|}{ Flower } \\
\hline Color & Maroon/purple & $\begin{array}{l}\text { Reddish/dark red/red/ } \\
\text { blue/ purple }\end{array}$ & Red-yellow & Dark red \\
\hline Bloom period & 1 week & 12 days $/ 2$ weeks $/ 1$ month & 3 days/1 week & Around 2 weeks \\
\hline Smell & The smell of carcasses & The smell of carcasses & Smells & Smells \\
\hline \multicolumn{5}{|l|}{ Color of tuber } \\
\hline Suweg 1 & Reddish white & Reddish white & Reddish white & Reddish white \\
\hline Suweg 2 & - & Yellowish white & Yellowish white & - \\
\hline \multicolumn{5}{|c|}{ Exposure by sunlight } \\
\hline Suweg 1 & Negrak & Negrak & Negrak & Negrak \\
\hline Suweg 2 & Hieum & Hieum & Hieum & Hieum \\
\hline
\end{tabular}



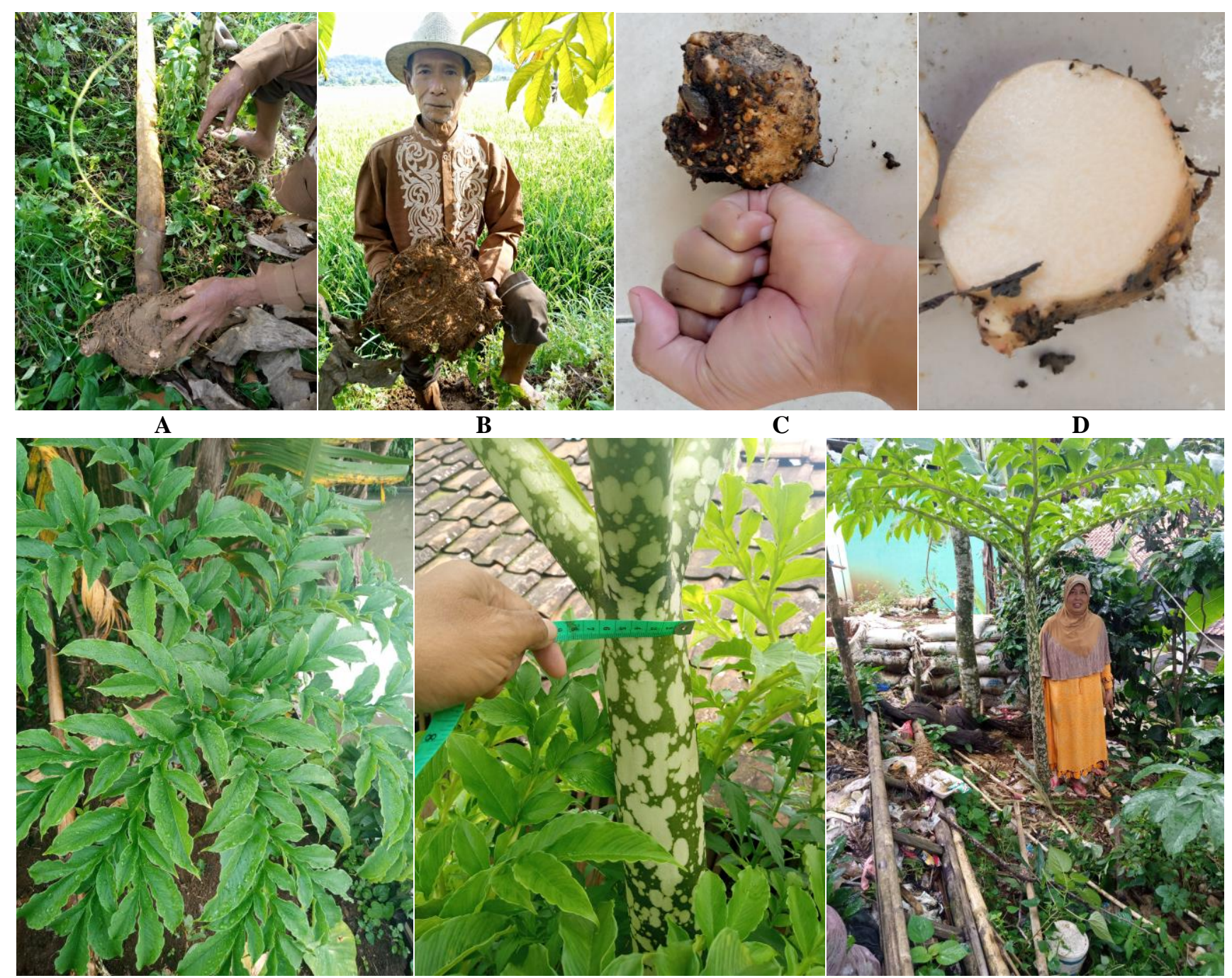

B

D

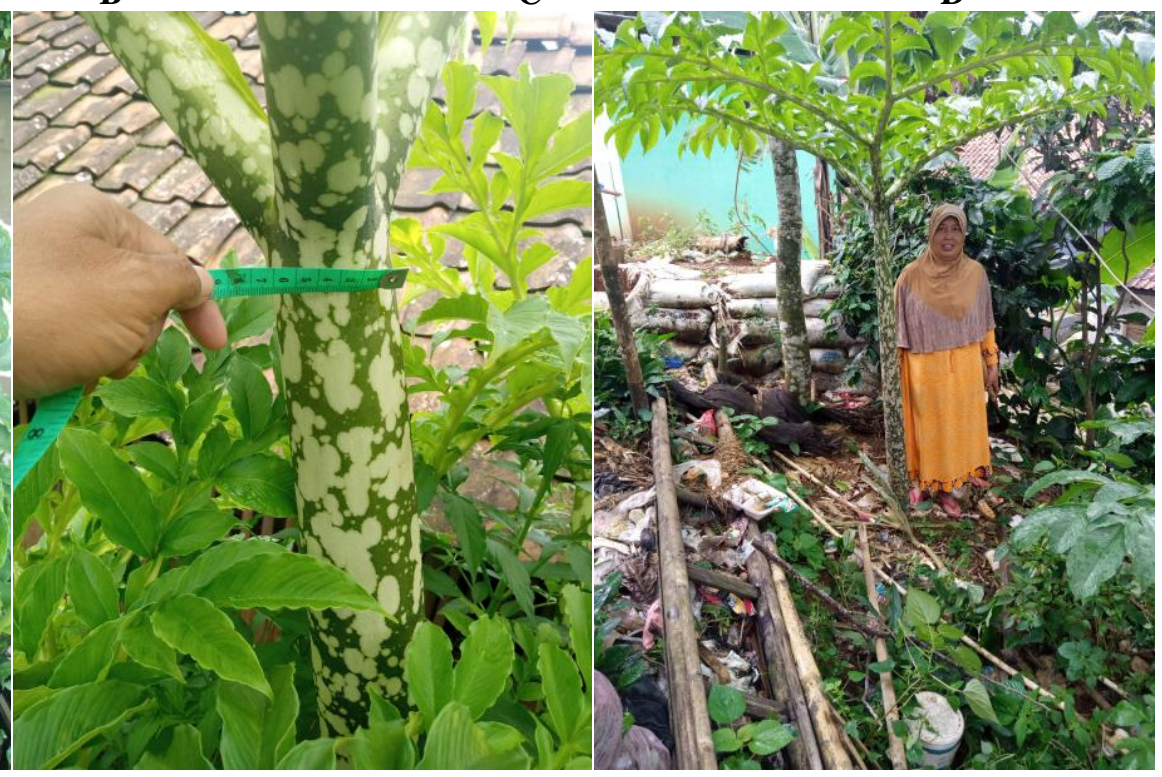

E

F

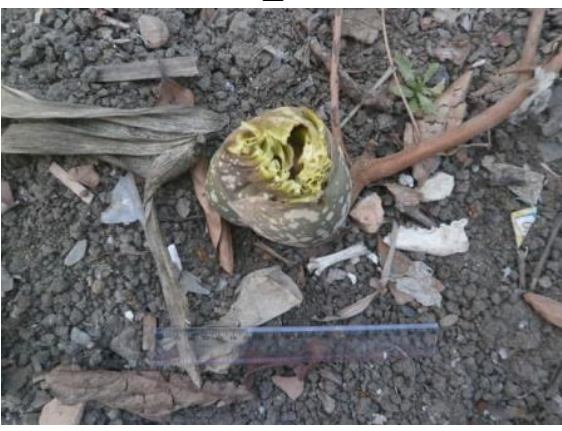

H

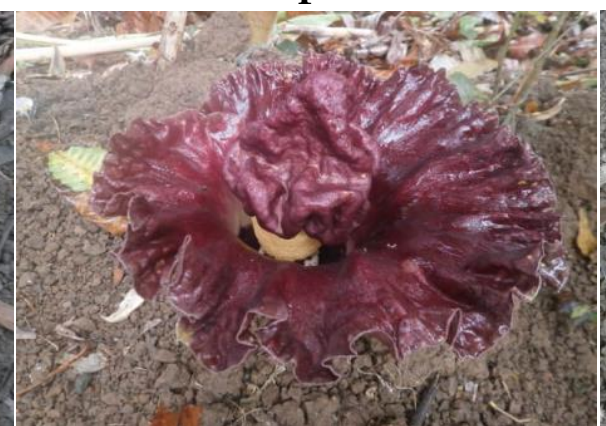

I
$\mathbf{G}$

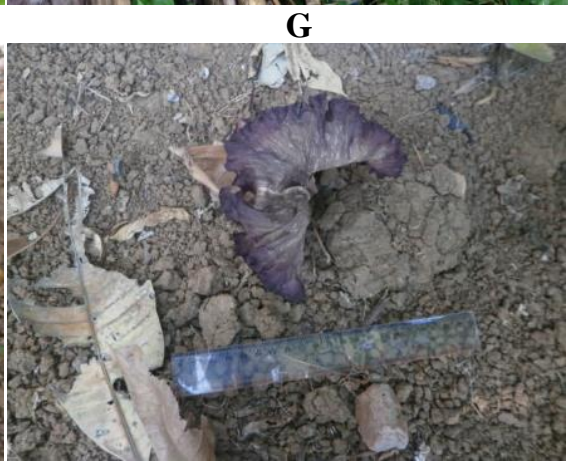

J

Figure 2. Morphology of suweg. Tuber size (A, B, C) and color of tuber flesh (D); leaf-blade (E), petiole (F), and height (G); blooming period $(\mathrm{H}, \mathrm{I})$ and withering period of flower $(\mathrm{J})$

In addition, there are also local terms or languages used by the community to explain their knowledge related to the morphology of leaf. The local term referred to is rampidak, rubak, ngadimprak, regegean, lesang/limit, teu kasap, nyeprot, leueur, and sa tangtung. Rampidak/rubak/ ngadimprak means wide in size. Lesang/the edge is slippery. Teu kasap has the meaning is not right. Nyeprot means the shape or size that the lower part is larger than the other part. Leueur shows the condition is slippery liquid. $S a$ tangtung means that it is as tall as a human.

Table 1 informs that there are similarities and differences in people's knowledge or perceptions related to suweg flower. An example of the similarity of perceptions is related to the blooming period of suweg flower for 1 week. Meanwhile, an example of the difference in perception is related to the color of suweg flower. 
Specifically, in the Cipulus and Cilancang Villages, some people did not know the suweg flower. This is because some communities have never seen flowers bloom in the environment around them, especially in land managed by the community such as home gardens and gardens.

Table 1 inform that the community classifies suweg into several groups, both based on the color of tuber flesh or exposure by sunlight. The community also mentioned several local terms or names related to this grouping, namely negrak and hieum. Negrak is a local term that indicates a place where objects or materials (in this case is suweg) that are in that place are exposed to direct sunlight without any obstructions. Meanwhile, hieum is a local term that indicates a place where objects or materials in that place are mostly obstructed by other objects (especially by leaf canopies) from exposure to sunlight.

Furthermore, the community stated that there were some differences in the suweg that grew in the negrak and hieum areas. Suweg that grow in negrak areas has larger tubers and petioles than those grown in hieum areas. On the other hand, the suweg that grows in the hieum area has a small tuber and its petioles are ulanyen (small) or begang (thin) or jangleung (tall, but thin).

In relation to the nomenclature, Literature search results that the local name suweg which is used by the community is identical to the popular local name used by the people of Cisoka Village, Cikijing Sub-district, Majalengka District (Mutaqin et al. 2020a, b). In addition, in other regions of the world, there are several local names, including buk khan in Thailand, suvarna gedde in Kannada, suran in Fijian, suranakanda in Hindi, ole in Bengali, oluo in Oriya, kanda gadda in Telugu language, elephant foot yam in English, koniaku in Japan (Singh and Wadhwa 2014); karnai kizhangu in the Namakkal-Tamilnadu District (Ramanathan et al. 2014); kidaran in a local language of Sabaramaguwa, one region in-Sri Lanka (Dharmadasa et al. 2016); syntiew-phylla in the local language of Meghalaya, one region in India (Singh et al. 2010); and karnaikilangu in a local language of Kerala, one region in India (Yabesh et al. 2014).

In relation to public information that suweg has certain morphological characteristics, this is in line with several other scientific studies. Ethically, Permatasari et al. (2014) state that the characteristics of the suweg can be seen from several morphological characters such as roots, tubers, leaves, and petioles. Anil et al. (2011) state that several variables that can be used as evaluations for systematic or variant of $A$. paeoniifolius include tuber size, tuber skin color, petiole color, petiole surface, leaf color, leaf color, and leaf texture.

In more detail, suweg has several morphological characteristics related to tuber organs, roots, leaves, and flowers. Public information related to the morphological character of suweg tuber is similar to the results of several scientific studies. Ethically, Singh et al. (2010) mention that this plant has tubers that are perennial, bulbiferous, globose, depressed, 20-25 x 15-20 cm, covered with dark brown skin. Sulistiyo (2015) explains that suweg has tubers with budded eyes, rather smooth texture, yellowish surface, pink or white tuber flesh, and not itchy. Govi et al. (2017) state that the tuber flesh of A. paeoniifolius is purplish yellow and the tuber skin is blackish brown. Yuzammi (2017) informs that the tuber of suweg has dark brown in color and $15 \mathrm{~kg}$ in weight.

In association with root morphology, public's knowledge in several aspects is in line with several scientific literature. Govi et al. (2017) inform that $A$. paeoniifolius has roots that grow on tubers with a length of about $50-60 \mathrm{~cm}$. Singh et al. (2010) state that the root of $A$. paeoniifolius is spreading root.

The public's knowledge related to leaf morphology is in some ways in line with some of the results of scientific research. Kurniawan et al. (2011) inform that the suweg leaves are split with oval-shaped like egg and winged rachis, have a diameter of $100-150 \mathrm{~cm}$, the petiole has a warty-thorny and grooved surface. In wild variants, the petioles are dark brown-greenish brown and slightly warty or smooth, whereas in the cultivation variant, the petioles are pale-green green. Both variants have a whitish-green dot. Singh et al. (2010) state that leaves decompound, radical, only 1 or 2 , smooth, forked, vary in size; rounded petiole, tapering, ca $130 \times 15-20 \mathrm{~cm}$, more or less smooth, green with pale blotches, indefinite very small dark dots; leaflets rounded, oval, ovate, elliptic-oblong, acuminate, 5$20 \times 2-15 \mathrm{~cm}$, slightly dark green upper surface, and pale green lower surface. Sedayu et al. (2010) inform that the petiole of suweg is usually strongly warty, rarely smooth, always blotched, and never stripped. Permatasari et al. (2014) mention that the petiole of the suweg has light green, dark green, light greenish-yellow, and brownishgreen color. Yuzammi et al. (2017) mentioned that petiole of the suweg has a diameter of $20 \mathrm{~cm}$, about $2 \mathrm{~m}$ in height, and has a pale green to dark green or blackish green with small or large size patches. Sulistiyo (2015) explains that suweg have a rather rough petiole with rounded spots.

In relation to flower morphology, some information from the public is in line with some of the results of other scientific studies. In general, the main characteristic of the Amorphophallus is that the tuber produces an evil-smelling inflorescence with a terminal sterile spongy phallic appendage enclosed in a spathe. Male flowers are on the upper part of the sterile zone of the spadix and female ones are below. It has a single petiole and a compound leaf that dies down before the plant flowers (Widjaja 1987). In particular, Kite and Hettersceid (2017) inform that suweg flowers have a smell like rotten meat. In more detail, Singh et al. (2010) mention that inflorescence is stacked, 5-18 x 2-12 cm, pale, smooth, monoecious, spadix, attached to the ground, and appears when the plant is destitute of leaves. It is large spathe, leathery, campanulate, broad shape with base and limb separated by a shallow constriction, smooth on both sides, strongly undulate, pale green on outside near the base, deep green on the middle part, spreading limb, orbicular, coriaceous and fleshy, maroon or purple on the above, usually with white spot on the below. It has stout and cylindric spadix, with a dark purple pyramidal appendage, $8-15 \mathrm{~cm}$ in diam., broad spadix-appendix, minute filaments, numerous anthers. Style is about four 
times the height of the ovary; large stigma, trilobed, and yellowish in color.

In association with folk classification, information or public knowledge is in line with some scientific research results in certain matters. In general, Iskandar (2018) states that the community in distinguishing variations is based on morphological character, ecological characteristics, and utilization. More specifically, Mutaqin et al. (2020a) state that according to the community in Cisoka Village, Cikijing Sub-district, Majalengka District, suweg can be classified into several variants based on the petiole, color of tuber meat, a taste of tuber meat, and place of growth (light intensity, soil texture, and soil color). Ethically, $A$. paeoniifolius has two variant forms, namely $A$. campanulatus f. hortensis as wild variant and $A$. campanulatus $\mathrm{f}$. sylvestris as a cultivation variant (Widjaja 1987). Anil et al. (2011) inform that A. paeoniifolius var. paeoniifolius is a wild variant and $A$. paeoniifolius var. campanulatus is a cultivation variant. Heriyansyah et al. (2017) inform that differences in growing locations can lead to the presence of suweg variants such as differences

\section{Habitat and growth of the suweg}

The community informed that suweg can grow on a broader spectrum of biophysical environments. The environment in which suweg grows more clearly can be seen in Table 2 and Figure 3.

Table 2 informs that in general, the community's knowledge of the environment for growth is the same. Specifically related to land, people in Jagasari Village, in petiole to bring up 2 variants, namely suweg beras (rice suweg) and suweg ketan (sticky rice suweg). Rice suweg has a light green of petiole color. Sticky rice suweg has a dark green of petiole color. In addition, Sulistiyo et al. (2015) state that differences in growth location also gave rise to variants of porang (Amorphophallus muelleri B), plants that are one family with suweg, which can be seen from several morphological differences, namely leaf blade (color, length, width, and number), petiole (diameter, length, color, and shape/color pattern), bulbil (weight), and tuber (weight).

More specifically related to differences in characters of the suweg due to differences in place as a result of exposure to sunlight, in some ways following some scientific literature. Mutaqin et al. (2020) inform that the community in Cisoka Village mentioned that in hieum (shaded area), the suweg have thin petioles, whereas in negrak (open area) the petioles are thick. Ethically, Sahoo et al. (2016) inform that exposure to sunlight intensity can affect vegetative growth in vegetation such as canopy width and plant height.

generally, inform that the suweg grows in the home garden or garden, but some information that the suweg grows on the pond edge. Pond, in general, is part of the home garden or garden. Meanwhile, the community in Sindangpanji Village informed us that the suweg can grow in a more diverse land use compared to community information from other villages.

Table 2. Knowledge of the community around Mt. Ciremai, West Java, Indonesia about the environment grows of the suweg

\begin{tabular}{lllll}
\hline \multirow{2}{*}{ Description } & \multicolumn{1}{c}{ Cipulus } & \multicolumn{1}{c}{ Cilancang } & \multicolumn{1}{c}{ Jillage } \\
\cline { 2 - 5 } & Home garden, garden & Home garden, garden & Home garden, garden & $\begin{array}{l}\text { Home garden, garden, rice field } \\
\text { edge, pond edge }\end{array}$ \\
\hline Land & & & Hot, cold & Hot, cold \\
Air condition & Hot, cold & Hot, cold & Rain & Rain \\
Season condition & Rain & Rain & Various types of soil & Various types of soil \\
Soil condition & Various types of soil & Various types of soil & Various species & Various species \\
Nearby plants & Various species & Various species & Varies \\
\hline
\end{tabular}

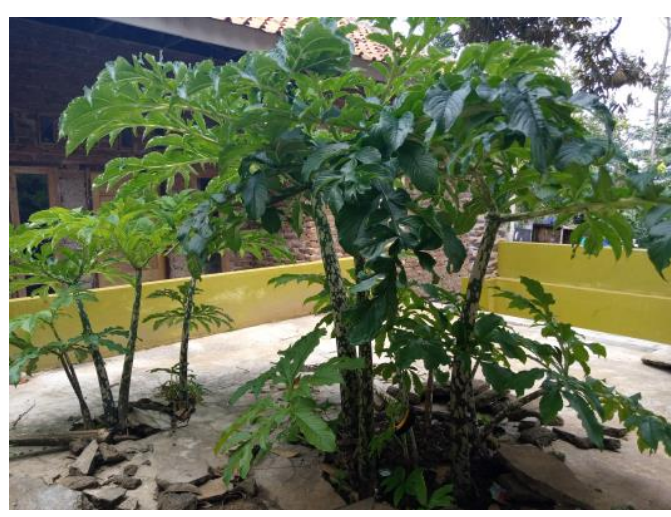

A

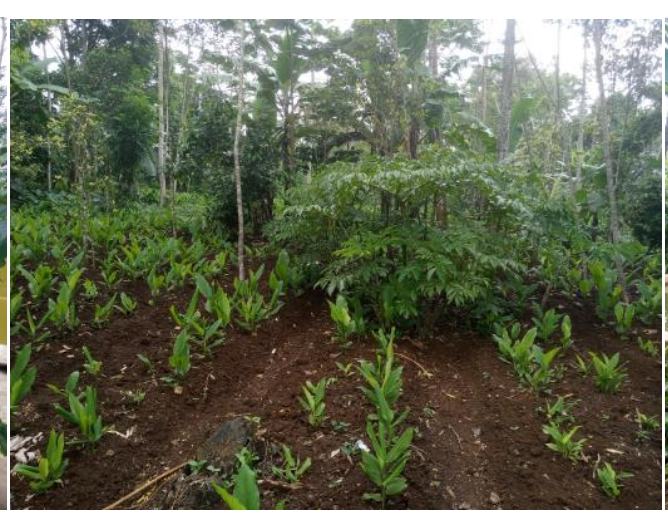

B

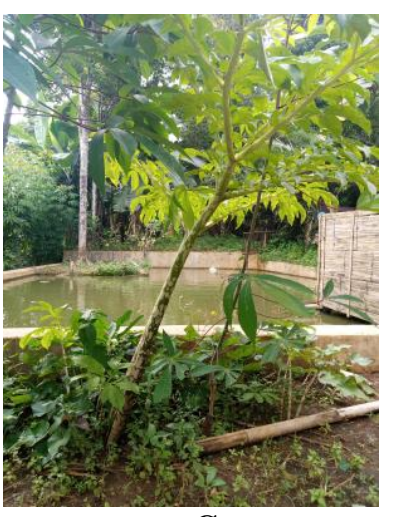

C

Figure 3. Habitat of the suweg: home garden (A), garden (B), and pond edge (C) 
Hot and cold conditions, according to information from the people, are related to sun exposure to a place. The hieum area usually has a tiis (cold) air condition. Meanwhile, the negrak (open area), generally, has hot air condition.

Regarding the season, the community informed that the suweg began to appear at the beginning of the rainy season and grew until the beginning of the dry season which was marked by yellowing or withering of leaf blades and petioles. In the dry season, suweg does not grow, which is named by the community with the term of paeh (dead).

The community informed that the suweg can grow in various colors, textures, or soil conditions. The colors of the soil in question include hideung (black), beureum (red), and brown soil. The texture or condition of the soil in question includes sandy, lendo (soft to hoe), and riduh (lots of fertilizer). Furthermore, the community informed that the suweg could grow more optimally in hideung soil (because there was a lot of humus) or lendo soil or riduh soil.

In addition, the community informed that the suweg can grow with various species of plants, including with eurih (Imperata cylindrica (L.) P. Beauv) or areuy (vines). The public further informed that the suweg that grows together with eurih or is wrapped around by areuy will grow teu sae (not optimal) because it is covered by the eurih or areuy.

Public's knowledge of the suweg habitat in some ways is in line with several scientific sources. Mutaqin et al. (2020a, b) state that according to information from the community in Cisoka Village, Majalengka District, suweg grows in several types of land, both in non-cultivated land types such as forests or in cultivated land types such as home gardens, gardens, rice field edges, and pond edges. Meanwhile, ethically, Yuzammi (2018) states that generally, Amorphophallus plants are terrestrial plants. The genus Amorphophallus is widely spread in the tropics in Asia, Africa, the Pacific Islands, and some other areas in the subtropic (Widjaja 1987). Yuzammi et al. (2017) inform that generally, suweg has a broader spectrum of growing environments. Santosa et al. (2017) state that $A$. paeoniifolius has wide agro-ecological adaptation and exhibits suitability for agroforestry systems. Hidayat (2019) informs that the suweg is found in the teak plantation forest.

In relation to information from the public that suweg can grow in cold or hot air conditions, this consideration is in line with some scientific literature. Mutaqin et al. (2020) inform that the people in Cisoka Village, Majalengka District mentioned that the suweg grows in tiis (cold) conditions in the hieum (shading area) or hot conditions in the negrak (open area). Ethically, this plant is found growing in areas with an open or shaded environment (Permatasari et al. 2014). Heriyansyah et al. (2017) find suweg in several places with a temperature range between 26-31 ${ }^{\circ} \mathrm{C}$. Budiman and Arisoesilaningsih (2012) conclude that monthly temperatures and the percentage of radiation either simultaneously or partially determined the growth of A. muelleri's vegetative and corm, plants that are related to suweg. Furthermore, Byju et al. (2018) state that suweg is potentially highly resistant to future climatic changes.

In association with the public's knowledge which states that the suweg grows during the rainy season, the conception is in line with some of the results of scientific studies. Mutaqin et al. (2020b) state that based on information from the people in Cisoka Village, Majalengka District, suweg grows during the rainy season marked by the emergence of leaf buds at the beginning of the rainy season and ends during the dry season marked by yellowing or falling leaves.

In relation to the public's knowledge which states that suweg can grow in various conditions of soil (such as color and texture), the conception is, in some ways, in line with some scientific researches. Iskandar et al. (2018) state that people can classify land as a growth medium based on color. Specifically, Mutaqin et al. (2020a, b) inform that the people in Cisoka Village mention that suweg can grow in various conditions of soil such as clay, sandy, red, brown, and black soil. Ethically, Permatasari et al. (2014) reveal that suweg grow in places with clay, sandy loam, and loose soil conditions. Meanwhile, Hafsah et al. (2018) inform that soil $\mathrm{pH}$ influences the distribution of Amorphophallus. Sahoo et al. (2016) inform that the level of soil media fertility affects the corm yield of $A$. paeoniifolius. Venkatesan et al. (2013) inform that planting media containing organic material in various conditions affect plant height and canopy width. In addition, Budiman and Arisoesilaningsih (2012) conclude that soil calcium (Ca) content radiation either simultaneously or partially determined the vegetative growth and corm of A. muelleri, plants that are one family with suweg.

In association with information from the public that in one area, suweg can grow with various species of plants, this conception is in line with some of the results of scientific research. Mutaqin et al. (2020a, b) inform that residents in Cisoka Village know that the suweg can grow with various species of plants, both cultivated plants (such as cassava or Manihot esculenta Cranz and taro or Colocasia esculenta (L) Schott.) or those that are not cultivated plants (such as Cyperus rotundus L. and Eleusin indica L.). Ethically, Permatasari et al. (2014) reveal that several species of trees and shrubs are found growing around the suweg. Hidayat (2019) informs that the suweg was found along with several other species of plants such as Imperata cylindrica (L.) Raeusch., Caesalpinia sappan L., Costus spiralis (Jacq.) Roscoe, Ficus montana Burm.f., and Paspalum conjugatum P.J. Bergius. Meanwhile, Chandra (2014) informs that $A$. paeoniifolius can be planted in an intercropping system with perennial plants, namely Psidium guajava L. Jata et al. (2019) inform that $A$. paeoniifolius can thrive in intercropping systems with annual plants, namely Vigna radiata L. Kumar et al. (2014) informed that $A$. paeoniifolius can grow with other plant species such as Colocasia esculenta and Curcuma longa on land with cropping systems. More clearly, Jata et al. (2018) inform that in cropping systems, A. paeoniifolius planted with other species of plants produce good growth such as related to the height of pseudostem and canopy spread. 
In association with information from the public that the suweg cannot grow and develop optimally if the surrounding places of growth are eurih (reeds) or are covered by areuy (vines), this conception is in line with the results of searching the scientific literature. Mutaqin et al. (2020a) inform that lack of or do not grow optimally when covered by vines (such as Piper betle L.) or reeds (Imperata cylindrica (L.) P. Beauv). In addition, Kuamr et al. (2019) inform that several species of plants such as Mimosa pudica L., Stachytapherta jamaicensis Syn: S. indica, Convolvulus arvensis var. linearifolius, Indigofera hirsute, Commelina benghalensis L., Cardiospermum microcarpum, Pennisetum polystachion (L.) Schultes, and Cynodon dactylon (L.) Pers. is a weed that can interfere with the growth of A. paeoniifolius. Meanwhile, Weerarathne et al. (2016) mention that Cyperus rotundus L., Digitaria sangunalis (L.) Scop., Eleusine indica (L.) Gaertn. spp. indica, Cynodon dactylon (L.) Pers., Mimosa pudica L., Commelina diffusa L., and Lantana camara L. are common weed of cocoyam, plants that are related to Amorphophallus. Meanwhile, the distribution and structure of the weed itself are influenced by the prevailing climate, crop types, soil types, and crop sustainability (Mahgoub 2019).

\section{ACKNOWLEDGEMENTS}

The authors would like to thank everyone, institutional, or stakeholders who have supported this research, especially Ministry of Research and Technology/National Research and Innovation Agency, and people of Cipulus, Cilancang, Jagasari, and Sindangpanji villages of Majalengka District, Indonesia. This research was supported by Program Disertasi Doktor (Doctoral Dissertation Program) of Prof. Denny Kurniadie.

\section{REFERENCES}

Albuquerque UP, Ramos MA, de Lucena RFP, Alencar NL. 2014 Methods and techniques to collect ethnobiological data. In Albuquerque UP, Cruz da Cunha LVF, Paiva de Lucena RF, Alves RRN. (eds.). Methods and Techniques in Ethnobiology and Ethnoecology. Springer Science + Business Media, New York.

Anil SR, Siril EA, Beevy SS. 2011. Morphological variability in 17 wild elephant foot yam (Amorphophallus paeoniifolius) collections from southwest India. Genet Resour Crop Evol 58 (8): 1263-1274.

Budiman, Arisoesilaningsih E. 2012. The predictive model of Amorphophallus muelleri growth in some agroforestry in East Java by multiple regression analysis. Biodiversitas 13 (1): 18-22.

Caruso E, Grace O. 2015. Ethics in ethnobotanical research: intellectual property rights, international agreements, and best practice. In: Caruso E. (eds) Conducting and communicating ethnobotanical research: A methods manual. Global Diversity Foundation, Morocco.

Chandra KK. 2014. Evaluation of growth and economic parameters of Curcuma longa and Amorphophallus paeoniifolius intercrops in medium-aged Psidium guajava orchard. Caribbean J Sci Technol 2: 392-398.

Cikijing Sub-district Agricultural Counseling Center. 2019. BPP agriculture counseling program in Cikijing Sub-district. Cikijing Subdistrict Agricultural Counseling Center, Majalengka. [Indonesian]

Curci J. 2010. The protection of biodiversity and traditional knowledge in international law of intellectual property. Cambridge University Press, Cambridge, UK
Derebe AD, Roro AG, Asfaw BT, Ayele WW, Eide AKH. 2019. Effect of solar UV-B radiation exclusion on physiology, growth, and yields of taro (Colocasia esculenta (L.)) at different altitudes in tropical environments of Southern Ethiopia. Scientiae Horticulturae 256: 1-10.

Dharmadasa RM, Akalanka GC, Muthukumarana PRM, Wijesekara RGS. 2016. Ethnopharmacological survey on medicinal plants used in snakebite treatments in Western and Sabaragamuwa Provinces in Sri Lanka. J Ethnopharmacol 179: 110-127.

Dou H, Niu G, Gu M, Masabni JG. 2017. Effect of light quality on growth and phytonutrient accumulation of herbs under control environments. Horticulturae 3 (36): 1-11.

Food and Agriculture Organization of the United Nations. 2017. Watershed management in action: Lesson learned from FAO filed projects. Food and Agriculture Organization of the United Nations, Rome.

Government Regulation of the Republic of Indonesia Number 37 of 2012 about Watershed Management. [Indonesia]

Govi DK, Andalil R, Sundaramoorthy B, Narayana SKK, Parameswaran SR. 2017. Comparative macro-microscopic atlas of two aroids used in Siddha medicine. J Ayurveda Med Sci 2 (4): 256-260.

Guo Y. 2010. Local knowledge: a free path to the academic autonomy-my commentary on "Management in China". Chinese J Manag 4: 475488.

Hafsah, Azrianingsih R. Masri M. 2018. Map of edible Araceae based on abiotic factors in Gowa District, South Sulawesi. J Environ Eng Sustain Tech 5( 2): 52-60.

Hassan MO, Hassan YM. 2019. Effect of human activities on floristic composition and diversity of desert and urban vegetation in a new urbanized desert ecosystem. Heliyon 5: 1-10.

Heriyansyah F, Soetopo L, Saptadi D. 2017. Exploration and identification of the morphological characteristics of the Suweg plant (Amorphophallus campanulatus BI) in East Java. J Produksi Tanaman 5 (3): 377-382. [Indonesian]

Iskandar J. 2018. Ethnobiology, Ethnoecology, and Sustainable Development. Plantaxia, Yogyakarta. [Indonesian]

Jata SK, Nedunchezhiyan M, Maity SK, Mallikarjun M. 2018. Intercrop and drip irrigation effects on growth, yield, water-use efficiency and economics of elephant foot yam (Amorphophallus paeoniifolius). Indian J Agro 63 (4): 506-512.

Jata SK, Nedunchezhiyan M, Maity SK, Mallikarjun M. 2019. Fertigation effect on elephant foot yam (Amorphophallus paeoniifolius) + green gram (Vigna radiata) intercropping system. Indian J Agric Sci 89 (12): 44-48

Kite GC, Hetterscheid WLA. 2017. Phylogenetic trends in the evolution of inflorescence odours in Amorphophallus. Phytochemistry 142: 126-142.

Kohsaka R, Rogel M. 2019. Traditional and local knowledge for sustainable development: empowering the indigenous and local communities of the world. In: W. Leal Filho et al. (eds.), partnerships for the goals, encyclopedia of the UN sustainable development goals. Springer Nature, Switzerland.

Korieocha DS, 2014. Weed control in national root crops research institute Umudike and its recommendation. Res J Agric Environ Manag 4 (1): $1-4$

Kuamr JS, More SJ, Byju G, Sunitha S, Veena SS, Nedunchezhiyan M, Ravi V. 2019. Effect of new generation herbicides on weed management, corm yield, and economics of elephant foot yam [Amorphophallus paeoniifolius (Dennst.) Nicolson]. Intl J Chem Stud 7 (3): 1213-1218.

Kumar A, Pandey SD, Patel RK, Rai RR, Srivastava K, Nath V. 2014. Studies on the feasibility of intercropping under litchi based cropping system. Ecoscan 5: 101-109.

Kurniawan A, Wibawa IPAH, Adjie B. 2011. Species diversity of Amorphophallus (Araceae) in Bali and Lombok with attention to genetic study in A. paeoniifolius (Dennst.) Nicolson. Biodiversitas, 12 (1): 7-11.

Mandal R, Nag S, Tarafdar J, Mitra S. 2016. A comparison of efficiency parameters of SSR markers genetic diversity analysis in Amorphophallus paeoniifolius (Dennst.) Nicolson. Brazilian Arch Biol Technol 59: 1-7.

Mahgoub AMMA. 2019. The impact of five environmental factors on species distribution and weed community structure in the coastal farmland and adjacent territories in the northwest delta region, Egypt. Heliyon 5: 1-33.

Mao S, Shen Y, Deng H. 2018. Multipurpose plant utilization in ethnic areas of Guizhou, southwest China. Ecol Indic 90: 547-553 
Martin GJ. 1995. Ethnobotany: a method manual. Chapman and Hall, London.

Mutaqin AZ, Fatharani M, Iskandar J, Partasasmita R. 2018. Utilization of Araceae by local community in Cisoka Village, Cikijing Sub-district, Majalengka District, West Java, Indonesia. Biodiversitas 19 (2): 640Majalen
651.

Mutaqin AZ, Kurniadie D, Iskandar J, Nurzaman M, Partasasmita R. 2020a. Ethnobotany of suweg (Amorphophallus paeoniifolius): Folk classification, habitat, and traditional conservation in Cisoka Village, Majalengka District, Cimanuk Watershed Region, Indonesia Biodiversitas, 21 (2): 546-555.

Mutaqin AZ, Kurniadie D, Iskandar J, Nurzaman M, Partasasmita R. 2020b. Ethnobotany of suweg, Amorphophallus paeoniifolius: Utilization and cultivation in West Java, Indonesia. Biodiversitas 21 (4): $1635-1644$

Nedunchezhiyan M, Ravindran CS, Velumani R, 2013. Weed management in root and tuber crops in India: Critical analysis. J Root Crops, 39 (2): 13-20.

Newing H, Eagle CM, Puri RK, and Watson CW. 2011. Conducting Research in Conservation: Social Science Methods and Practice. Routledge, London.

Permatasari M, Pitoyo A, Suratman. 2014. The diversity of suweg (Amorphophallus campanulatus) in the ex-residency area of Surakarta based on morphological, anatomical, and isozyme banding patterns. Bioteknologi 11 (1): 11-18. [Indonesian]

Phungpracha E, Kansuntisukmongkon K, Panya O. 2016. Traditional ecological knowledge in Thailand: Mechanisms and contributions to food security. Kasetsart J Soc Sci 37: 82-87.

Ramanathan R, Bhuvaneswari R, Indhu M, Subramanian G, Dhandapani R. 2014. Survey of ethnobotanical observation on wild tuberous medicinal plants of Kollihills, Namakkal district, Tamilnadu. J Med Plants Stud 2 (4): 50-58.

Sahoo B, Nedunchezhiyan M, Acharyya P. 2016. Yield potential and economics of elephant foot yam (Amorphophallus paeoniifolius) as influenced by fertility levels, light interception, and soil resistance. Indian Agricult 60 (1): 65-69.

Santosa E, Lian CL, Sugiyama N, Misra RJ, Boonkorkaew P, Thanomchit K. 2017. Population structure of elephant foot yams (Amorphophallus paeoniifolius (Dennst.) Nicolson) in Asia. PLoS ONE 12 (6): e0180000. DOI: 10.1371/journal.pone.0180000.

Sedayu A, Eurlings MCM, Gravendeel B, Hetterscheid WLA. 2010. Morphological character evolution of Amorphophallus (Araceae) based on a combined phylogenetic analysis of $\operatorname{trn} \mathrm{L}, r b \mathrm{~L}$, and LEAVY second intron sequences. Bot Stud 51: 473-490.

Singh B, Tham BBT, Rabha NN. 2010. Taxonomical notes on Amorphophallus paeoniifolius (Dennst.) Nicolson var. campanulatus (Decne) Sivadasan (gigantic flower): a new record for Meghalaya. J Econ Taxon Bot 34 (3): 492-492.
Singh A, Wadhwa N. 2014. A review of multiple potentials of Aroid: Amorphophallus paeoniifolius. Intl J Pharm Sci Rev Res 24 (1): 5560.

Statistics of Majalengka District. 2018. Cikijing Sub-district in figures. Central Statistics Agency of Majalengka District, Majalengka. [Indonesian]

Statistics of Majalengka District. 2019. Cikijing Sub-district in figures. Central Statistics Agency of Majalengka District, Majalengka. [Indonesian]

Sulistiyo RH, Soetopo L, Damanhuri. 2015. Exploration and identification morphological character of elephant foot yam (Amorphophallus muelleri B.) in East Java. J Produksi Tanaman 3 (5): 353-361 [Indonesian]

Venkatesan K, Jansirani P, Kamalkumar R, Sujatha R. 2013. Effect of organic management on the growth and yield of elephant foot yam. J Root Crops 39 (2): 260-262.

Voeks R. 2017. Ethnobotany. In: Richardson D, Castree N, Goodchild MF, Kobayashi A, Liu W, Marston RA (eds.). John Wiley \& Sons, Ltd., New York.

Wang D. 2017. Local governance and local knowledge. J Bus Manag, 5: 415-419

Watson CW. 2011. The role of researcher. In: Newing $\mathrm{H}$ (ed.). Researching conservation: A social science perspective. Routledge, London.

Weerarathne LVY, Maramble B, Chauhan BS. 2016. Intercropping as an effective component of integrated weed management in tropical root and tuber crops: A review. Crop Protect 95: 89-100.

Widjaja EA. 1987. Morphological, anatomical, and chemical analyses of Amorphophallus paeoniifolius and related taxa. Reinwardtia 10 (3): 271-280.

Xu W-B, Svenning J-C, Chen G-K, Zhang M-G, Huang J-H, Chen B, Ordonez A, Ma K-P. 2019. Human activities have opposing effects on distributions of narrow-ranged and widespread plant species in China. PNAS Latest Articles:1-8. DOI: 10.1073/pnas.1911851116.

Yabesh JEM, Prabhu S, Vijayakumar S. 2014. An ethnobotanical study of medicinal plants used by traditional healers in the silent valley of Kerala, India. J Ethnopharm 154: 774-789.

Yuzammi, Kurniawan A, Asih NPS, Erlinawati I, Hetterscheid W. 2017. The Amorphophallus of Indonesia. Center for Plant Conservation Botanic Gardens, Indonesian Institute of Sciences, Bogor.

Yuzammi. 2018. The diversity of aroids (Araceae) in Bogor Botanic Gardens, Indonesia: Collection, conservation, and utilization. Biodiversitas 19 (1): 140-152.

Zambrana NYP, Leret RC, Bussmann RW, Macia MJ. 2014. The influence of socioeconomic factors on traditional knowledge: a crossscale comparison of palm use in Northwestern South America. Ecol Soc 19 (4): 9. 